\title{
Learning with Stories: A Personal Case Study Approach in Communication
}

\author{
Nirupama Akella, MA \\ Instructional Designer \& Doctoral Assistant, Innovation in Learning Center, \\ University of South Alabama
}

This paper is a reflective paper-an attempt by the researcher to explore, explain, and understand the workings and benefits of the case study method from the perspective of a learner. The researcher opens with a discussion of up the issue discussing the case study method as a learning and teaching medium in applied disciplines, by providing her own learning experience in her graduate communication class. She further supports her perspective with suitable theory.

\section{I ntroduction}

Instructors in fields of applied communication and theory, such as public relations, ethics, law, advertising, and social effects, are using the case study method to teach important concepts, theories, and issues in class. Case study method teaching and learning forms an important contemporary pedagogical tool in the academic field of communication. There needs to be current research supporting or negating this position.

This paper presents a learner's viewpoint of how an academic topic was taught in a graduate communication class using the case study method. This forms the beginning section of the paper. The following three sections lay the theoretical foundation of the paper. The researcher wraps up her paper with a discussion about the workings and benefits of the case study method.

\section{Learning with Cases}

This paper is a personal observation of my experience of learning about a qualitative communication research method through a case study rather than systematic, empirical research into the practice of case study as a teaching and learning tool. I am a communication graduate student at a large Midwestern university. In my third semester, I had to enroll for a research methods class. This class, 501: Qualitative Research Methods, is a core course and has to be taken by every graduate student. The class, designed to be a conference class for a maximum of 15 students, is offered every fall as an evening class from 6 p.m. to half past eight. The class follows the traditional lecture format with additional class readings and assignments on various research methods, paradigms, concepts, theories, traditions and practices. Outcome evaluations done at the end of the semester have a research and a written examination component. Students have to submit an original piece of research and take an examination to pass the

Case studies are steeped in the ethnographic tradition, in which the researcher observes an event, or is an active participant in the event. Case study research does not restrict the researcher to the role of an observer and interviewer. Hence, case studies can be autobiographical in nature and filled with rich description and dialogue. course.

In fall 2009, the Qualitative Research Methods class (scheduled on Monday evenings) was a large class of 22 students, which was more than the designated number. There were two course texts and a number of additional readings and assignments. The class was due for two lectures on participant observation in the month of October. And I was not looking forward to it. It would be the same old lecture where my classmates and I would sit with our heads resting on our elbows, listening to a monologue by the professor. There would be hushed chatter and a 
couple of yawns. The professor would give the class a ten-minute break, and my classmates and I would rush into the corridor, thankful to escape the ordeal. Some of us would stretch our legs, while others would drink water and eat chips from the vending machine. Then the class would return to the conference room. The door would close, and then it would be time to catch a few winks before the class would end at precisely half-past eight. Perhaps the professor would call attention to the sleeping class by giving a written assignment.

It would be exactly like that, I thought, entering the conference room located in the corner of the communications department building, Room 1263.

"Another boring class..."

I sat down in my designated chair and waited for the professor, idly doodling on my notepad. The professor entered the room at precisely six p.m., and the class began. I stifled a yawn and opened my text. There was a flipping of pages as everyone seemed to be counting the page numbers of the text. The professor sat down and said, "We are supposed to discuss participant observation tonight, but I am not going to give a lecture, and you are not going to take notes. Instead, you are going to read a story..."

I sat up-a story... that WAS different.

The chatter had stopped. My neighbor put away his mobile ...

The professor handed out copies of a thick article and said,

"That's it for this evening. Let me take your attendance and you can go ... read the story at home..."

I had wrongly assumed that it would be the same old lecture format, but instead, the class had been saddled with a story. I put the article in my bag and left class.

I went home, threw my bag on the floor and switched on the television. I did not even glance at the story that night, or the next morning. It was not until the weekend that I thought about it. I had finished all my assignments for the coming week and was sitting idly. And, I thought, it is a story after all...

I searched for the article, found it, and started reading Street Corner Society by William F. Whyte (1993). After the first page, I didn't want to put it down; I wanted to know more. And so I kept on reading the story; the story of a Harvard doctoral student, William Foote Whyte, who decides to do his PhD research on the housing situation in slums. The story took me on a journey of his experiences, emotional encounters, interactions, and thoughts during his stay in the slums of Cornerville.

\section{The Heavy Stuff}

\section{In the Classroom}

The storytelling genre is becoming popular again in lecture halls and classrooms of communications departments and colleges (Cox, 2001). This is because ordinary lectures consisting of a monologue by an 'authority figure' do not mentally stimulate the audience (Kreps, 1984). Stories, on the other hand, are firstperson accounts of what happened, how it happened, and to whom it happened. They involve the audience as they call upon them to resolve a crisis or problem with a theoretical rationale or explanation (Cox, 2001). In a nutshell, stories compel a listener to think critically (Cox, 2001). Stories are illustrations of real-life episodes and take on the form of cases. A case is a snapshot of human activity and crisis, with real characters, dialogues, and a problem (Kreps, 1984).

Case studies are used to teach students how to effectively apply communication theory to actual situations. The emphasis is on a message and action-centered perspective. A student analyzing a case must first understand the situation: what is going on, who is the main character. The student must recognize and identify the problem and address the issue with relevant strategies pertaining to the academic theory and literature (Schnelle, 1967; Mier, 1982). The reader should experience the emotion and mental trauma of the protagonist and grapple with

InSight: A Journal of Scholarly Teaching 
dilemmas as if they were his or her own. And when the dilemma is solved, the reader should feel relieved. That is the primary focus of the case study method: The audience has to have a 'feel good' experience at the end of the discussion. Development of knowledge base and critical thinking is a necessary by-productsomething that has to happen for the achievement of the solution (Mier, 1982).

A typical case study must incorporate rich background information that provides the setting for further action and behavior. This background should provide the student with appropriate clues as to why the protagonist is facing a problem (Kreps, 1984). There should be dialogue between the characters in the story, which should be as realistic as possible, providing background information about the characters, their education, personalities. The listener should be able to visualize these characters from the description in the case. The most enriching cases describe-show and not tell-“the process by which actions take place" (Ulrich, 1953, p. 31).

A case study clarifies the role, function, and usage of theory in a professional workplace: how someone can use theory to effectively resolve workplace problems. Students are apt to remember and engage in continuous learning if they learn by active participation (Mier, 1982). Knowledge learned through passive participation is bound to reside in short-term memory. This limits a student's ability to analyze and comprehend situations and theories (Mier, 1982). It is crucial to select case material that reflects course information and explains important and appropriate theories. It is the responsibility of the instructor to present the story in an engaging fashion with appropriate usage of visual aids, audio, and role-play exercises (Kreps, 1984).

The main attraction of the case study method is the active participation of the audience. This means that the listener should be physically and mentally involved in the case (Kreps, 1984). Instructors often use the exercise of role-play, where students are given roles of the characters in the case. The students then engage in dialogue and action so they can experience the crisis unfolding. This provides a further insight into the situation and helps students to develop critical thinking skills, thus bridging the gap between theory and practice (Kreps, 1984). It is also the responsibility of an instructor to create a class environment conducive for case study teaching and learning (Glover \& Hower, 1953). A student should not hesitate to ask questions, clarify doubts, and think aloud.

This calls for a permissive atmosphere in which they (students) feel free to put forth their ideas and questions without the instructor reacting in the form of rejection, derision, blame, or authoritarian injunctions to think along other lines preferred by the instructor at that moment. It is essential to develop a supportive class atmosphere of communication, non-judgmental behavior, cooperation, empathy, and spontaneity. These factors help the student experience firsthand the workplace environment envisioned in the case (Gibb, 1961).

After reading and discussing the case in depth during class, a student must be able to successfully answer the case questions. Case analysis represents the outcome of the comprehension and explanation process (Kreps, 1984). A typical case analysis must comprise three primary parts: (a) the opening problemidentification statement, (b) Problem analysis, and (c) recommendations or solution. A case analysis report must be systematic, logically organized, realistic, wellresearched, and have a theory base (Bernthal, 1975).

Case studies have the power and ability to engage every type of student: the kinesthetic student learns best through case studies by getting physically involved in the case study activities. The tactual learners find the case study method most appropriate, as it engages the emotional ego. In short, the tactual learner identifies with the verbal exchanges and drama of the case study. The case study method is also suitable for the auditory learners who are able to establish, identify, and understand complex relationships, concepts, ideas, and theories during discussion. Visual learners also benefit from this method, which gives them the opportunity to see in person the problem and the unfolding of events. Class 
activities, such as role-playing and games, allow them to see how theory can be used to address an issue (Kosa, 2008). "Tell me and I will forget, show me and I may remember, but involve me, and I will understand and remember forever" (Kosa, 2008, p. 45).

\section{Theoretical Framework}

Academic storytelling in the form of case studies is a recognized qualitative research tool (Dooley \& Skinner, 1977). Case study work was first introduced in the academic spheres of medicine, library science, business, legal education, and social work. The goal of the case study method is to present the actual "meaning" of action and behavior (Avis, 1995). Hence, storytelling or case study research is described as a qualitative alternative paradigm where the objective is to find not the 'truth' but the 'meaning': "a representation [of reality] from one particular point of view, in contrast to the quantitative understanding of reality as truth... a social and physical reality which exists independently of our experiences of it" (Avis, 1995, p. 1206). This means that a story in academic literature seeks to present a subjective meaning of an event. This event or real-life episode can be interpreted in various ways by many people. All interpretations are true and valid meanings of the real-life episode. This is in contrast to quantitative research, which states that research exists to find the "truth," which is objective in nature and devoid of any social, physical, or emotional interpretation.

The goal of case study researchers is to provide ways of understanding this meaning and experience (Schwandt, 1994). Thus, one case study can have different meanings colored by social, physical, and emotional reality. Case study inquiry is based on the view that knowledge is not absolute or devoid of any subjectivity. Knowledge is relative and is a creation of the interaction between researcher and the researched (Guba \& Lincoln, 1994; Avis, 1995; Reed, 1995; Strubert \& Carpenter, 1999). In other words, knowledge is not an independent entity but is dependent on human interaction. This epistemological basis forms the foundation of case study research. Richards explains that case research cannot be value free and have a single conclusion or "truth." He says that case research is subjective and objective at the same time. This means that a case study researcher or reader cannot and does not approach a case without any "prior theory in mind" (Richards, 1993, p. 40).

Maclntyre (1984) states that man is a storytelling animal. According to him, telling stories that detail an event or a process is critical to human experience and learning (1984). He further clarifies that storytelling can be described as a "narrative enquiry" (Maclntyre, 1984; Flyjvberg, 2006, p. 240). His view is further propounded by a phenomenological approach, which states that stories are snapshots of human experience. This approach is advocated by Christensen (1987) when he says that similar stories build knowledge about a particular phenomenon. Christensen further states that these stories are described as cases (1987). Thus, he notes that case studies are central to human learning and knowledge utilization (Christensen, 1987; Flyvbjerg, 2006, p. 222). The approach focuses on the aspect of human interaction, and states that human learning does not evolve in a straight, vertical, or horizontal line (Flyvbjerg, 2006). Rather, cases present human interaction which can project and diverge in many different ways. Thus, exposure to case studies builds human experience and learning (Flyvbjerg, 2006). The phenomenological approach echoes the essence of the qualitative constructionist theory (Avis, 1995).

The constructivist theory argues that all reality has meaning that is a construction of human interaction (Avis, 1995). This means that a case study researcher is involved in the process of reality construction. Thus, the case study researcher can write the case constructing one reality. The audience reads the case and constructs another reality. The reality of the researcher can be different from that of the audience and that of the researched. But every reality construction represents subjective meanings. In case study research, "objective knowledge is a

InSight: A Journal of Scholarly Teaching 
myth" (Avis, 1995, p. 1207). Case study research also falls within the paradigm of qualitative narrative analysis (Mishler, 1986). The basic premise of this argument holds that individuals develop and create constructions of reality and make sense of meaning and their world by telling and listening to stories (Ricoeur, 1981; Smith, 1981; White, 1981; Connelly \& Clandinin, 1986, 1990; Sacks, 1986, 1992; Riessman, 1990, 1991, 1993; Bruner, 1991; Clandinin \& Connelly, 1994; Wiltshire, 1995). Case studies are steeped in the ethnographic tradition, in which the researcher observes an event, or is an active participant in the event. Case study research does not restrict the researcher to the role of an observer and interviewer. Hence, case studies can be autobiographical in nature and filled with rich description and dialogue. The listener can take any perspective and create any construction. The ultimate goal of the case study is to make the audience think and become critical enquirers and reality constructivists (Atkinson, 1992; Mishler, 1979, 1986, 1990; Bailey, 1998).

Lincoln and Guba explain that a case moves from the particular to the general. A case has many solutions as it depicts one story (Lincoln \& Guba, 1984; Perry, 1998). Thus, they conclude that a case is descriptive and biased. Hunt (1991) and Parkhe (1993) argue that cases are the study of "observable" phenomena, and therefore fall into the realm of objective research. Hunt further states that cases are not prescriptive (Hunt, 1991). Cases do not provide an answer or the solution to the problem, but encourage readers and researchers to probe and think further to propose suitable appropriate answers. Thus the focus is on "how do" rather than on "how should" (Hunt, 1991). Hence, case study utilizes the scientific paradigm of realism with an emphasis on the induction research methodology.

Hunt (1991); Leplin (1986); and Tskouas (1989) state that case study research embraces the scientific paradigm of positivism. Cases represent a mix of induction and deduction methodologies (Perry, 1998). On one hand, cases have a narrative descriptive quality which takes support from pure induction methods (Perry, 1998; Mishler, 1986; Parkhe, 1993). Yin states that descriptive cases are positivist based, while exploratory cases which further knowledge and human learning adopt a realistic scientific paradigm (Yin, 1994; Flyvbjerg, 2006). Richards further clarifies that cases are a mix of prior theory and newly compiled theory emerging from the raw data (Richards, 1993, p. 40).

\section{Playing a Role in Applied Disciplines}

Contemporary teaching methods in the academic field of communication are narrow (Robbins, 1975). The emphasis is on teaching students "what to do" rather than "how and why to do it" (Robbins, 1975). In other words, educators are confining students to the 'novice' level of competency and comprehension. Novice teaching methods include textual analysis and printed notes by the teacher and the formal, traditional lecture. This method is based on the assumption that students learn "best when someone else tells them what to do" (Robbins, 1975, p. 38). Thus, students spend time reading, listening to an instructor, and taking notes. The instructor decides when and what students should learn and periodically evaluates their level of knowledge (Robbins, 1975).

Students do not engage in critical thinking or in logical and symbolic organization of academic content. They simply follow what is presented to them, read, and verbalize it without understanding its value, importance, and meaning (Cascio, 1991). There is minimal student- teacher interaction, resulting in a failure to organize relevant thoughts and concepts for use in future situations. In addition, this passive method of teaching does not encourage "students' abilities of discovery, problem solving, and collaboration with peers to formulate discussion, thoughts, and ideas (Reich, 1991). The novice method fails to facilitate and teach students to solve problems with the use of related theory (Digman, 1995). The traditional novice method stifles competency building, leaving the graduate communication student unfit for professional work in the real world (Digman, 1995). 
Applied communication disciplines are usually taught by the 'craftsman' or workshop method. The focus is to train students to fit into the professional field. Here again, the emphasis is on 'doing something' rather than on 'understanding the how and why of a situation or process" (Robbins, 1975). Students write assignments and theses, produce documentaries, write copy and advertising text, business communication memorandums and letters to display and prove their declarative and procedural knowledge (Robbins, 1975; Blanchard \& Thacker, 2003). However, these activities fail to teach the student to understand how and why he or she is doing that activity. Workshop method develops craftsmanship or expertise in doing activities (Robbins, 1975). But students need to learn more to be able to function as communication practitioners. Current academic study of communication is slowly making the transition towards the 'expert' method of teaching. Instructors have realized that they need to broaden the focus of their teaching and make it relevant to real life. The 'expert' method of teaching equips students to be able to:

(a) Examine a real-life situation and discover inherent communication problems and opportunities;

(b) Research the communication environment they are a part of and critically study diverse aspects of the audience, media, and technology, including organizational constraints placed by them;

(c) Formulate communication goals, targets, and objectives;

(d) Evaluate alternative communication paradigms, theories, and strategies to achieve their objectives;

(e) Engage in a high level of critical thought and logical cognitive organization (Robbins, 1975, p. 38).

Thus, the expert method of teaching argues for the holistic competency development of the communication student. This method takes the form of case study teaching or storytelling in a communication classroom. However, there is a definite lack of empirical research detailing the benefits and limitations of case study teaching. Questions such as the number and names of communication subfields currently using this method, including the rate of success, have to be empirically investigated. Case study methods are being used in contemporary classrooms of business, education, information technology, organizational communication, and mechanical engineering (McDade, 1995). The aim of such applied disciplines, as explained by McDade (1995) and Gerring (2004), is to be able to identify possible workplace problems in a realistic paradigm and offer feasible solutions. Applied academic disciplines require students to think creatively and critically, analyze, and be cognitive, categorical decision makers (Robbins, 1974; Gerring, 2004). This means that students of applied disciplines have to move beyond the 'craftsman' stage and acquire expertise in the field (Gerring, 2004). Academic fields such as business marketing, financial management, nursing, accounting, research and program evaluation, abnormal and industrial psychology, counseling psychology, information technology, architectural design, instructional design, and mechanical engineering are some of the contemporary academic users of case studies.

However, applied communication disciplines such as media theory and law, advertising, public relations, and research methods do not use this method as an official classroom methodology for imparting knowledge (Flyvbjerg, 2006). Given the critical link and influence on human learning, researchers McDade (1995) and Kosa (2008) opine that the explicit lack of case study as a viable classroom teaching method in applied communication disciplines is astonishing. McDade (1995) points out that cases are a way of sustaining a student's interest, as they encourage students to think and analyze, make associations, and draw possible conclusions. Cases help students to remain focused on the issue and develop a working knowledge of the feasibility of textual fact in the "real" world (McDade, 1995, p. 10). This is crucial for applied communication disciplines because as the name suggests, the aim of such disciplines is to equip students to apply classroom knowledge in the workplace (Kosa, 2008).

InSight: A J ournal of Scholarly Teaching 


\section{I ntegrating Theory and Practice}

The story did what the lecture could not do...

I learn best when the reading material involves drama and emotion. I need to feel I am a part of the literature presented to me in order to identify, understand, and critically analyze its various dimensions. Whyte's story managed to engage me at an emotional level. After the first page, I felt sorry for Whyte, the poor PhD student. I am also a student, and know how difficult it is to live on a student salary. The reading material had already gotten me hooked and involved with the main character. I wanted to know how Whyte, with his financial problems, was going to do a comprehensive research study.

I had my text nearby in case I needed to consult it about methodological terms and concepts. After all, Whyte's article was only a story. I was in for a delightful surprise: I didn't need to refer to my text at all. Whyte's article showed me everything. The paper was a combination of realism and my interaction with it. It depicted a journey of Whyte which was believable and humorous. By the time I finished the article, I knew everything about the qualitative research method of participant observation-the theory, pitfalls, validity, and reliability concerns. And I had not read the textbook. I had just read the story of Whyte and understood and enjoyed his emotional roller-coaster ride in Cornerville. I lived through the entire process of data collection with Whyte, the protagonist of the story. I was there with him when he befriended his gatekeeper, Doc, who later became his source for information. I was at the edge of my seat when Whyte went on a drinking spree and indulged in illegal activities to fit in with the slum members; I grappled with his mental dilemma of either being objective and neutral, or become involved, to lose perspective and become biased.

The following week in class (the last one on participant observation method), I found myself actively discussing and participating in a discussion on the method. Whyte's article had successfully bridged the gap between theoretical knowledge and the practical application of that knowledge in the field. We all saw and understood how scientific knowledge was shaped by administrative concerns. In this case, we identified Whyte's doctoral grant funding committee as the primary stakeholders. Whyte was "forced" to choose the slum of Cornerville for his research because his finances, controlled by the doctoral funding committee, dictated it. Thus, Whyte's study taught us that all scientific research has to be conducted within administrative constraints.

We were questioning each other and encouraging a regular flow of interaction. Here I must mention that my instructor made it possible for us to exchange ideas, debate, and argue about research issues of reliability and validity; she created an open and informal classroom setting where each one of us felt comfortable to discuss and critically think. We developed respect for each other as individuals and students. This active participation, I am sure, will serve al I of us in good stead when we work with diverse people in the workplace. In addition, dreary research issues of gate keeping, participant observation, and field notes came alive. We engaged in a short skit immersing ourselves in the various characters in Whyte's article. Someone became Doc, the gatekeeper, a few others enacted roles of the doctoral-grant-funding committee, and someone took up the role of Whyte. The students playing the roles kept changing, as all

Here I must mention that my instructor made it possible for us to exchange ideas, debate, and argue about research issues of reliability and validity; she created an open and informal classroom setting where each one of us felt comfortable to discuss and critically think. We developed respect for each other as individuals and students. 
of us took turns. The rest of the class was the audience. This role-playing made us critically comprehend, sympathize, and also come up with preventive solutions. Each one of us was able to see what Whyte was faced with-his research dilemmas, his mental tussle between objectivity and subjectivity-Should he join the residents of Cornerville on their drinking binge, or should he refrain from becoming one of them and remain a fly on the wall? Similarly, the audience as well as the actors could understand Doc's dilemma-Should he betray his longtime friends and include a stranger among them on false pretenses, or should he tell the truth? Role-playing also made us appreciate the storytelling-narrative-enquiry inherent in case studies. We realized that there is no "single" truth, but that what we learn builds towards our knowledge and understanding of academic phenomena and the human endeavor to uncover truth's many facets.

We had moved beyond the "novice" method of learning where we just read what was given to us, repeated it, and listened to a lecture. We had successfully learnt the "craft" of participant observation. But all of us had accomplished something more-something we would not have achieved with a traditional, ordinary lecture. We had become participants in the lecture. We had shaped, influenced our instruction. We had become experts at the qualitative research method of participant observation. The cognitive activity of reading, analyzing, evaluating, and synthesizing Whyte's experiences, attitude, and perception had taught us firsthand the function and course of action of the participation-observation method. Reading the case had made us aware of the various drawbacks and consequently we reflected on the holistic process of choosing an appropriate methodology for research. Hence, the case study method had propelled us to engage in critical thought and emerge as logical, cognitive individuals. It helped us gain a real-life perspective on how things get done in real life. The case study method had blended the theory of participant observation with its practice in the real world.

This kind of situated learning also made us realize that research does not occur in a vacuum but happens in a context. Research attitudes, behaviors, and actions cannot be predetermined but are a function of the context. Whyte did not plan and theorize that his research method would lead him to participate in illegal activities. His experience made us

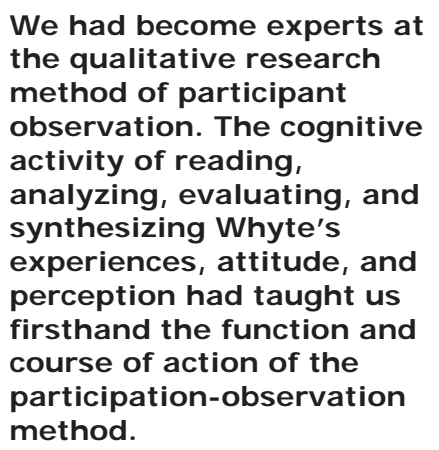

aware that all research is contextual. That evening, all of us had crossed from being students to learners who had engaged in knowledge acquisition, knowledge application, knowledge evaluation, and cognitive critical thought. The case study method had successfully integrated Bloom's taxonomy of educational objectives. It made us all holistically and cognitively competent in the realm of research.

At the end of the class, we came out feeling excited and refreshed. We felt happy for Whyte, as by now he had become an extension of our personal selves. We were personally involved in Whyte's successes and failures, and we experienced a sense of relief and joy when his research yielded successful results.

\section{Conclusion}

Cases or stories encourage active, participatory learning. The student has control over material he or she reads. Consequently, students are able to unite theory and practice to develop a holistic and comprehensive view of the situation. And cases are generalizable-you can apply learned and interpreted material of one story in a situation to another story in a similar situation. But empirical investigation detailing such effects of the case study method needs to be done in all fields of academic instruction. My case shows that learning new material by way of case studies is helpful, and beneficial. But the research purpose would have been better

InSight: A Journal of Scholarly Teaching 
served had my personal research investigation been supported by quantitativesurvey evidence. Hence, a mixed-methods research design could be deemed suitable for further research into the identified problem.

\section{References}

Akella, D. (2010). Learning together: Kolb's experiential theory and its application. Journal of Management \& Organization, 16(1), 100-112.

Atkinson, P. (1992). The ethnography of a medical setting: Reading writing, and rhetoric. Qualitative Health Research, 2, 451-474.

Avis, M. (1995). Valid arguments? A consideration of the concept of validity in establishing the credibility of research findings. Journal of Advanced Nursing, 22(6), 12031209.

Bailey, P. H. (1998). Patients, family caregivers', and nurses: Stories of acute exacerbation events of chronic pulmonary disease (Unpublished doctoral thesis). The University of Edinburgh, Edinburgh, UK.

Bailey, P. H. \& Tilley, S. (2002). Storytelling and the interpretation of meaning in qualitative research. Journal of Advanced Nursing, Blackwell Science Ltd. 38(6), 574583.

Brenthal, W. (1975). Case analysis in organizational behavior and the practice of management, unpublished instructional mimeograph. University of Colorado.

Bruner, J. (1991). The Narrative construction of reality. Critical Inquiry, 18(1), 1-21.

Blanchard, N. P. \& Thacker, J.W. (2003). Effective training: Systems, strategies, and practices, (2nd ed.) Pearson Education: Prentice Hall.

Cascio, W. F. (1991). Applied psychology in personnel management (4th ed). Englewood Cliffs, NJ: Prentice Hall.
Christensen, C. R. (with Hansen, A.J.) (Ed.) (1987). Teaching and the case method, Boston: Harvard Business School Press.

Clandinin, D. J. \& Connelly, F. M. (1994). Personal experience methods. In Denzin, N. L. \& Lincoln, Y. S. (Eds.). Handbook of Qualitative Research, Sage Publications, London.

Connelly, F.M. \& Clandinin, D. J. (1986). On narrative method, personal philosophy, and narrative unities in the story of teaching. Journal of Research in Science Teaching, 23(4). 293-310.

Cox, K. (2001). Stories as case knowledge: Case knowledge as stories. Medical Education, 35(9), 862-866.

Digman, L. A. (1995). Strategic management: Cases. Houston, TX: Dame.

Dooley, A. R. \& Skinner, W. (1977). Chasing case methods. The Academy of Management Review, 2, 277-289.

Flyvbjerg, B. (2006). Five misunderstandings about case-study research, Qualitative Enquiry, 12(2), 219-245.

Gerring, J. (2004). What is a case study and what is it good for? American Political Science Review, 98(2), 341-354.

Gibb, J. R. (1961). Defensive communication, Journal of Communication, 11(3), 141-148.

Glover, J. D. \& Hower, R. M. (1953). Some comments on teaching by the case method: The case method of teaching human relations and administration. (Andrews, K. Ed.), Cambridge, Harvard University Press. 
Guba, E. G. \& Lincoln, Y. S. (1994). Competing paradigms in qualitative research. In Denzin, N. L. \& Lincoln, Y.S. (Eds), Handbook of Qualitative Research, Sage Publications, London.

Hunt, S. (1991). Modern marketing theory. Cincinnati, South Western.

Kreps, G. L. (1984). Using the case study method in organizational communication classes: Developing students' insight, knowledge and creativity. Paper presented at the meeting of International Communication Association Conference, San Francisco, CA.

Kosa, J. R. (2008). Tell a story. NJEA Review, 81, 3-10.

Leplin, J. (Ed.) (1986) Scientific realism. University of California Press, Berkeley: CA.

Macl ntyre, A. (1984). After virtue: A study in moral theory (2nd ed.). Notre Dame, IN: University of Notre Dame Press.

McDade, A. S. (1995). Case study pedagogy to advance critical thinking. Teachers College: Columbia University, 22(1), 9-10

Mier, D. (1982). From concepts to practices: Student case study work in organizational communication, Communication Education, 31, 151154.

Mishler, E. G. (1986). Research interviewing context and narrative. Harvard University Press, London.

Parkhe, A. (1993). "Messy Research", methodological predispositions and theory development in international joint ventures. Academy of Management Review, 18(2), 227268.

Perry, C. (1998). Processes of a case study methodology for postgraduate research in marketing. European Journal of Marketing, 32(9/10), 785802.
Reed, P. G. (1995). A treatise on nursing knowledge development for the 21st century: Beyond postmodernism. Advances in Nursing Science, 17(3), 70-84.

Reissman, C. K. (1990). Strategic uses of the narrative in the presentation of self and illness: A research note. Social Science and Medicine, 30(11), 1195-1200.

Reissman, C. K. (1991). Beyond reductionism: Narrative genres in divorce accounts. Journal of Narrative and Life History, 1, 41-68.

Reissman, C. K. (1993). Narrative analysis. Sage Publications, London.

Reich, R. B. (1991). The work of nations: Preparing ourselves for a 21st century capitalism. NY: Alfred A. Knopf.

Richards, L. (1993) Writing a qualitative thesis or grant application, In Beattie, K. (Ed.) So where's your research profile? A Research Book for Academics. Union of Australian College Academics, South Melbourne, Australia.

Ricoeur, P. (1981). Narrative Time. In W. J. T. Mitchell (Ed.), On Narrative, University of Chicago Press, Chicago, IL.

Robbins, J. C. (1975). Training the professional communicator: The case study method. Journal of Business Communication, 12(3), 37- 45.

Sacks, H. (1986). Some consideration of a story told in ordinary conversation, Poetics, 15(1/2), 127-138.

Sacks, H. (1992). Part IV Spring 1970. G. Jefferson (Ed.), In Lectures on Conversation, 2, Blackwell, Oxford.

Schwandt, T. A. (1994), Constructivist, interpretivist approaches to human inquiry. In N. L. Denzin \& Y. S. Lincoln0 (Eds), 
Handbook of Qualitative Research. Sage Publications, London.

Schmidt, M. \& Lipstreu, O. (1975), The case method, (Unpublished instructional mimeograph). University of Colorado.

Schnelle, K. (1967), Case analysis and business problem solving, McGraw-Hill: New York.

Smith, B. H. (1981), After thoughts on narrative. In W. J. T. Mitchell (Ed.), On Narrative University of Chicago Press, Chicago, IL.

Streubert H. J. \& Carpenter, D. R. (1992), Qualitative research in nursing advancing the humanistic imperative, J.B. Lippincott Company, Philadelphia.

Tsoukas, H. (1989) The validity of idiographic research explanations. Academy of Management Review, 24(4), 551-561.

Ulrich, D. N. (1953), The case method: The case method of teaching human relations and administration (Andrews, K. Ed.), Cambridge, Harvard University Press.
West, C., Farmer, J. \& Wolff, P. (1991), Instructional design: implications from cognitive science. Englewood Cliffs, NJ: Prentice-Hall.

White, H. (1981), The value of narrativity in the presentation of reality, in W. J. T. Mitchell (Ed.), On Narrative, University Press of Chicago, Chicago, IL.

Whyte, W. F. (1993), Street Corner Society, (4th ed.) University of Chicago Press, Chicago, IL.

Wiltshire, J. (1995), Telling a story, writing a narrative: Terminology in health care, Nursing Inquiry, 2(2), 75-82.

Yin, R. K. (1994) Case study research: Design and methods. Applied Social Research Method Series, 5 ( $2^{\text {nd }}$ ed. $)$, Sage, Newbury Park: CA.

Zhao, J. J. (1996), Using case studies for international business communication training, Business Communication Quarterly, 59(4), 1124.

Nirupama Akella is a PhD student in Instructional Design and Development at the College of Education, University of South Alabama. She is also employed as an Instructional Designer and doctoral assistant at the Innovation in Learning Center, University of South Alabama. Nirupama has master degrees in management, journalism, and communication. 